\title{
Discourse on Penistaan Agama of Basuki Tjahaja Purnama's Blasphemy Trial in Twitter
}

\author{
Fardan Mahmudatul Imamah \\ IAIN Tulungagung \\ imamah2012@gmail.com
}

\begin{abstract}
This study was conducted to map and elaborate how blasphemy was understood in social media, mainly Twitter. Beginning with the origins of the blasphemy law and some conflicts triggered by the law, this paper will explain the chronology of Ahok's case and how it becomes popular within netizen. The questions of the study are how the Indonesian netizen in social media understand the blasphemy case of Ahok and how they try to construct discourse with it. The findings are interrelated the hashtags that led in five issues, (1) the action of defending Islam, (2) defending ulama, (3) Muslim leader, (4) national security, (5) imprisoning Ahok, (6) election of the regional head. The network of actors is exposing the complexity of reactions of netizen. Indonesian netizen in social media understands blasphemy in two ways, using religious discourse and political discourse. The first constructs blasphemy as a threat for religion and state security. The second argues the religious discourse by proving blasphemy as a tool for achieving political power. Various issues are tried to identify "blasphemy" that at the same time used to identify certain groups/actors as enemies or allies. In the process of identification, there emerges a similar solidarity in interpreting the "blasphemy" based on a single interpretation of the religious source. However, there also emerges the discussion of how religious interpretation of blasphemy should not be used for political reason.

[Studi ini bertujuan untuk memetakan dan menjelaskan bagaimana penistaan agama dipahami dalam media sosial, khususnya Twitter. Penelitian ini dimulai dengan menjelaskan hukum penistaan agama dan beberapa konflik yang terjadi di Indonesia terkait penistaan agama, yang kemudian secara khusus fokus pada kasus Gubernur DKI Basuki (Ahok) Tjahaya Purnama. Ahok dianggap telah memicu kemarahan Muslim Indonesia karena pernyataannya terkait ayat Al Maidah 51 di
\end{abstract}


pertengahan September 2016. Rumusan masalah dalam penelitian ini adalah bagaimana netizen Indonesia memahami penistaan agama dalam kasus Ahok dan bagaimana mereka membangun diskursus tentangnya. Dengan menggunakan analisis hasbtag dalam Twitter, terdapat beberapa enam isu yang paling mendominasi terkait diskursus kasus Ahok, yakni (1) aksi bela Islam, (2) bela Ulama, (3) kepemimpinan muslim, (4) keamanan nasional, (5) memenjarakan Ahok, (6) pemilihan kepala daerah. Jejaring aktor dalam diskursus ini menunjukkan kompleksitas reaksi netizen. Secara, terdapat dua cara dalam memahami penistaan agama, yakni dengan menggunakan diskursus agama dan diskursus politik. Diskursus yang pertama memahami penistaan agama sebagai ancaman terhadap agama dan negara. Sedangkan diskursus yang kedua memahami penistaan agama sebagai alat politik. Berbagai isu digunakan untuk mengidentifikasi penistaan agama, yang secara bersamaan juga digunakan untuk mengidentifikasi seseorang atau kelompok tertentu sebagai musuh atau sekutu. Dalam proses mengidentifikasi, muncul cara memahami bahwa penistaan agama terjadi karena rendahnya toleransi terhadap pemahaman berbeda atas penafsiran agama yang tunggal. Meskipun, terdapat juga diskusi tentang interpretasi sumber agama yang seharusnya tidak digunakan untuk kepentingan politik.]

Keywords: blasphemy, twitter, Ahok.

\section{Introduction}

Blasphemy is a controversial issue in relation between religion and state which brings various responses of countries in dealing with. ${ }^{1}$ The re-emergence of the issue of blasphemy in the past years, not only in Indonesia, shows how state and citizen have their understanding and policies to "protect" religion from any

\footnotetext{
${ }^{1}$ Many powerful Muslim countries, such as Saudi Arabia, Iran, Pakistan, and Egypt, have powerful and broad blasphemy laws. For example, Saudi Arabia asserts that its Wahhabi interpretation of Islam is the only permissible one in the nation and other Muslims, such as Shia, Sufis, and Muslims who advocate for political reform or modernization may be labeled as apostates - individuals who have renounced authoritative Islam - deserving of flogging, imprisonment, or even death. Read Lebl, L. "Radical Islam in Europe.” Orbis,54 (1), (2010), 46-60.
} 
defamations and threats. ${ }^{2}$ For those reasons, the unexpected growth of perceptions about what is "blasphemy" which drives people actions is the prime subject of this research.

The paper discusses the trial of Religious Defamation toward the Governor of Jakarta, Basuki Tjahaja Purnama, better known as Ahok, because of his speech in Pulau Seribu commenting the verse of Quran, Al Maidah 51. After five months of trial, the Governor of Jakarta has been sentenced to two years in prison. Ahok was found to have legitimately and convincingly conducted a criminal act of blasphemy. The case of Ahok and the actions against him - which is most known as "Aksi Bela Islam"- have reached a total of 279,852,000 entries in the Google search engine, and total news reached 5,730 stories. The case has become trending the topic on Twitter in 25 hashtags and keywords, a special theme on the most popular talk show Mata Najwa, and the theme of Indonesia Lawyer's Club for twice. On Facebook, this theme has also been a center of debate in the past three months. ${ }^{3}$ There are so many materials of discourse on it, but this study will focus on social media in elaborating the discourse and its development of the meaning of blasphemy.

2 Since 2001, some Western countries, excluding the United States, enforced dormant blasphemy laws that punish individuals for criticizing or defaming God, religious beliefs, holy doctrines, or ridiculing religious figures - inspired, in large part, by demands from Muslim organizations and countries to castigate people for "defaming or insulting Islam or the Prophet" read Gabriel, B. They must be stopped: Why we must defeat radical Islam and how we can doit. New York : Martin's Press., 2008, Lebl, L. "Radical Islam in Europe." Orbis,54 (1), (2010): 46-60 and Phares, W. The War of Ideas: Jihädism against democracy. (New York : Palgrave, 2007). Islam is not the only protected religion in Europe; 36 countries (80\% of the region's 45 nations) have laws that penalize defamation of any religion, more read Pew Forum on Religion and Public Life. "Laws penalizing blasphemy, apostasy and defamation of religion are widespread." $21 \quad 2012$. http://www.pewforum.org/2012/11/21/laws-penalizingblasphemy-apostasyand- defamation-of-religion (accessed by May 7, 2017).mh

${ }^{3}$ http://dekandidat.com. Digitroops: Kasus Abok dan Aksi Bela Islam Paling Populer Tabun 2016. 22 Desember 2016. http://dekandidat.com/2016/12/22/digitroopskasus-ahok-dan-aksi-bela-islam-paling-populer-tahun-2016/ (diakses Juli 17, 2017). 
Social media now is about one of the most important elements to know what people perceive the world around them. Social Media is the forms of electronic communication through which users create online communities or share information, ideas, personal messages, and other content. Technically, social media is "a group of Internet-based applications that build on the ideological and technological foundations of Web 2.01, and that allow the creation and exchange of User Generated Content"*. Social media built on not only personal but also interest connection. This interest invites many people from various places to gain and to change a massive volume information about certain topics. ${ }^{5}$ The activities on social media will be also like an act in the real life through various channels for communication. ${ }^{6}$ There are different types of social media platforms, such as social networking sites (e.g., Facebook and Myspace), blogs and microblogs (e.g. Twitter), content communities (e.g., YouTube, Flickr, and Instagram), and so on. ${ }^{7}$ The different networks that people used explain their priority of community. ${ }^{8}$ Social media is the place for people try to relate each other for various purposes. ${ }^{9}$ Twitter for some scholars show great

${ }^{4}$ A. M. Kaplan and M. Haenlein, "Users of the world, unite! The challenges and opportunities of Social Media.”, Business Horizons, 53(1), (2010), 59-68.

${ }^{5}$ D. A. Gruber, R. E. Smerek, M. C. Thomas-Hunt, and E. H. James. "The realtime power of Twitter: Crisis management and leadership in an age of social media. ." Business Horizons, 58(2) (2015), 163-172.

6 D. S. Lassen and A. R. Brown, "Twitter: The electoral connection? Social Science”, Computer Review, 29(4) (2010), 419-436.

7 In early 2016, Indonesia Social Media Trend 2016 based on 1.033 respondent JAKPAT panel reports that Facebook ( $87 \%$ internet users) is still number one social media in Indonesia. Instagram $(69,21 \%)$ overtaking Twitter $(41,31 \%)$ and second place Path (36,29\%) and Google+ (20,08\%) are racing up. LinkedIn (7,53 $\%)$ and Snapchat $5,79 \%$ ) also catching up.

${ }^{8}$ A. Cochran, L. S. Kao, N. J. Gusani, J. W. Suliburk, and B. C. Nwomeh, "Use of Twitter to document the 2013 Academic Surgical Congress", The Journal of Surgical Research, 190(1) (2014), 36 - 40.

9 There is also the information about various goals of what people doing in their activities on social media, such as fun things $(52,22 \%)$, information $(43,91 \%)$, share interesting posts $(30,79 \%)$, share funny posts $(24,03 \%)$, feeling Blue $(21,53 \%)$, listen to a song $(21,14 \%)$, protest $(18,92 \%)$, sell something $(16,12 \%)$, cool location/place $(13,8 \%)$, and watch movies $(13,51 \%)$. 
promise for a reconfiguration of the structure of political discourses towards a broadening of public debate by facilitating social connectivity. ${ }^{10}$ People can be also aggressively share, comment and make certain content as national matters. Social media invites various perceptions, interpretations, goals, perspectives, and campaigns through its activities.

This paper observes social media as the main research object, specifically Twitter. The object of study is reduced by selecting prime tweets in the blasphemy discourse use hashtags for preferring Twitter account and tweets. It needs some applications on analyzing social media, such as Hashtagify and Netlytic.

Twitter, as a microblogging platform, was born in 2006. Its users are allowed to post 'tweets ${ }^{\text {"11 }}$ which can contain text, photos, videos, and outside web URLs in real time. Twitter is an awareness system that allows an immediate, fast, and widespread dissemination of information. ${ }^{12}$ This platform offers various goals to share news from different sources, resulting in a stream of information, opinions, and emotions $^{13}$ that presents a multi-faceted experience of ambient news. ${ }^{14}$ Within political discourses, some political actors as well as

10 Maireder, Axel, dan Julian Ausserhofer. "Political Discourses on Twitter: Networking Topics, Objects and People." in Twitter and Society, oleh K., Bruns, A., Burgess, J., Mahrt, M., \& Puschmann C. (Hrsg.) Weller. (New York: Peter Lang, 2013).

11 A tweet has a maximum of 140 characters. Individuals, organizations, and companies can create Twitter accounts on this platform. Twitter has 313 million monthly active users and 500 million tweets being sent per day. Read https://about.twitter.com/id/company accessed by September 20th, 2017.

${ }^{12}$ Kwak, H., Lee, C., Park, H., \& Moon, S. What is Twitter, a social network or a news media? Paper presented at the 19th International Conference on World Wide Web. NC: Raleigh, NC. doi:10.1145/1772690.1772751, 2010.

13 Oliveira, Papacharissi \& de Fatima. "Affective news and networked publics: The rhythms of news storytelling on \#Egypt." Journal of Communication, 62(2), (2012), 266-282.

14 Hermida. "Twittering the news: The emergence of ambient journalism. ." Journalism Practice, 4(3), (2010), 297-308. 
individuals use Twitter to spread information on political events and to state their opinions. ${ }^{15}$

The information can easily go "viral"- particularly where inaccurate information has a strong simple story and it will be different with reality which is complex and has context. The issues or information spread in social media through a hyperlink. Tweets are media objects connected to other objects by this hyperlink. This network of objects is part of the 'material' base of the networked public sphere, and following the links between those objects—surfing the web-is the central mode of activity to access information. ${ }^{16}$ The twitter hyperlink uses hashtag that are connected to events reported by mass media, at least in terms of topics taken up and quantity of messages sent. ${ }^{17}$ The other twitter agenda is likely to differ from the mass media agenda, "events and themes are filtered through the community's own established interests and news frames, resulting in a distribution of attention that is different from that of the mainstream media or of general public debate". ${ }^{18}$ It means that using discourse in social media will get broader perception without any filter from mainstream media and their frames on this issue.

This study limits the range of tweets from the November 2016 until 20 March 2017. For explaining the discourse, this study uses the same perspective by Axel Maireder \& Julian Ausserhofer in their research by two perspectives: (1) Networking topics in terms of the inclusion

15 Small, T. A. "What the hashtag? A content analysis of Canadian politics on Twitter." Information, Communication \& Society 14(6), (2011), 872-895.

16 Maireder, Axel, and Julian Ausserhofer. "Political Discourses on Twitter: Networking Topics, Objects and People." Dalam Twitter and Society, oleh K., Bruns, A., Burgess, J., Mahrt, M., \& Puschmann C. (Hrsg.) Weller. (New York: Peter Lang, 2013).

17 A. Bruns and J. E. Burgess. "\#Ausvotes: How Twitter covered the 2010 Australian federal election." Communication, Politics and Culture, 44(2), 2011: 37-56 and Moe, A. O, dan H. Larsson. "Studying political microblogging: Twitter users in the 2010 Swedish election campaign.” New Media \& Society; 14(5), (2011), 729747.

18 Bruns, A., and J. E. Burgess. "\#Ausvotes: How Twitter covered the 2010 Australian federal election." Communication, Politics and Culture, 44(2), (2011), page. 13 
of information, interpretation, and views into a debate; (2) networking actors, driven by@mentioning practices, resulting in new patterns of interaction between political actors and citizens that reshape the participation structure of the public sphere. ${ }^{19}$ The question is how the Indonesian people in social media understand the blasphemy case of Ahok and how they try to construct discourse with it. Hopefully, this research has academically relevance and socially significant for the discourse of blasphemy in Indonesia.

\section{The Case of Blasphemy in Indonesia}

The discourse of religious blasphemy in the recent years becomes problematic, unfinished cases and politically used for various goals. Center for Religious and Cross-cultural Studies show that some religious conflicts including the issues of religious blasphemy relate to the local political cases in some places. The annual report refers to the three cases (Sampang, Bekasi, and Kupang) of religious conflicts that have direct/indirect relation with the local political power before or after the local election. There are various religious issues that influence religious sentiment in the middle of political contexts, such as infidelity (sesat), conflict of worship places, and blasphemy.

The concept of blasphemy becomes more popular recently. Generally, blasphemy refers:

"To the acts of uttering profane, insulting or abusive language for something divine related to religion. In the Islamic context, blasphemy refers to a wide range of acts ranging from apostasy to cursing or slandering Allah and the Prophet Muhammad. Blasphemy also includes disrespect toward other holy messengers or religious beliefs. It is overlapped with infidelity, which is seen as the rejection of Allah, His revelation, and His messengers. Expression of religious opinions that are a variance

19 Maireder, Axel, and Julian Ausserhofer. "Political Discourses on Twitter: Networking Topics, Objects and People." in Twitter and Society, by K., Bruns, A., Burgess, J., Mahrt, M., \& Puschmann C. (Hrsg.) Weller. (New York: Peter Lang, 2013). 
with normative Islamic views can also be construed as blasphemy. So, blasphemy means behavior or language that shows disrespect of any prophet any religion." 20

Based on the report of Amnesty International in 2014, there are two laws that often used to target individuals who belong to minority religions, faiths and opinions, and particularly those who adhere to interpretations of Islam that deviate from the mainstream form of Islam in Indonesia. ${ }^{21}$ First, Law Number 1/PNPS/1965 on the Prevention of "Religious Abuse and/or Defamation", commonly known as the blasphemy law (Undang-Undang Penodaan Agama). This law can be used to imprison people for as long as five years simply because they have peacefully exercised their right to freedom of expression or to freedom of thought, conscience or religion, which are protected under international human right law. Second, the law that can be used to imprison people in expressing the freedom of thought is about "Incitement" provision in Law No.11/2008 on Electronic Information and Transaction (ITE) which have similarity been used to criminalize protected expression.

Indonesia enacted Presidential Decree No.1/PNPS/1965 on the Prevention of "Religious Abuse and/or Defamation". This Presidential Decree was passed by President Soekarno, the first president of Indonesia, to accommodate a request from Islamic organizations to prohibit mystical indigenous belief (aliran kepercayaan) which they believe could tarnish existing religions in Indonesia. ${ }^{22}$ President Soekarno signed the decree on 27 January 1965, but it was made law (Law No.5/ 1969) during President Soeharto's administration. Most of criminal prosecution and

\footnotetext{
20 Munawar, Iffatkhalid, \& Shamana, "Blasphemy Law of Islam-Misconceptions and Fallacy", Journal of Islamic Studies and Culture, Vo.3, No.1 (June 2015), 48-57.

21 Amnesty International, Prosecuting Beliefs Indonesia's Blasphemy Laws (London: Amnesty International, 2014), 7.

${ }^{22}$ A Freedom House Special Report. "Policing Belief the Impact of Blasphemy Laws of Human Right." freedombouse.org. t.thn. https://freedomhouse.org/sites/default/files/Policing_Belief_Full.pdf
} 
convictions in Indonesia for acts considered as blasphemy are due to this Presidential Decree. The blasphemy law covers two types of blasphemy acts: deviation (penyimpangan) from the six officially recognized religions and defamation (penodaan) of these religions as stipulated in article 1 and 4 respectively of President Decree No1/PNPS/1965.

The meaning of defamation "penodaan" is referred to Pasal 1 Undang-Undang No. 1/PNPS/1965:

"Setiap orang dilarang dengan sengaja di muka umum menceritakan, menganjurkan atau mengusabakan dukungan umum untuk melakukan penafsiran tentang sesuatu agama yang utama di Indonesia atau melakukan kegiatan-kegiatan keagamaan yang menyerupai kegiatankegiatan agama itu, penafsiran dan kegiatan mana menyimpang dari pokok-pokok ajaran dari agama itu."

(Every individual is prohibited in public from intentionally conveying, endorsing or attempting to gain public support in the interpretation of a certain religion embraced by the people of Indonesia or undertaking religious-based activities that resemble the religious activities of the religion in question, where such interpretation and activities are in deviation of the basic teachings of the religion).

However, in most blasphemy cases the prosecution has used Article 4 on the law which stimulates:

'Pasal 156 a KUHP memberi ancaman pidana lima tabun penjara bagi mereka yang dengan sengaja di muka umum mengeluarkan perasaan atau melakukan perbuatan yang bersifat permusuban, penyalahgunaan atau penodaan terbadap suatu agama yang dianut di Indonesia. Juga bagi mereka yang dengan sengaja di muka umum mengeluarkan perasaan atau melakukan perbuatan dengan maksud agar supaya orang tidak. menganut agama apa pun juga yang bersendikan Ketuhanan Yang Maba Esa." "Article 165a KUHP a maximum imprisonment of five years shall be punished for whoever in public deliberately expresses their feelings or engages in actions that: in principle is hostile and considered as abuse or defamation of a religion embraced in Indonesia; has the intention that a person should not practice any religion at all that is based on belief in Almighty God." 
In 1965, this provision was incorporated into article 156(a) of the Indonesia Criminal Code (kitab Undang-Undang Hukum Pidana/KUHP) in section 5 (five) of crimes against public order, and unlike Article 1 of the law, can be used directly for prosecution without first providing an administration warning under Article 2(1).

The problem of this law is the interpreting of 'penodaan' in the certain circumstance that in most of the cases using Indonesian Ulama Council (Majlis Ulama Indonesia/MUI) for defining it. The MUI began to gain more influence in 2005 after receiving open political support from former President Yudhoyono, who invited the MUI to make recommendations to shape government policy, including asking MUI to produce guidelines to be implemented by the government of "deviant religious teaching (aliran sesat)"23

The number of cases using this law for criminalizing religious issues increase significantly after Reformation Era. Director of Center for Religious and Cross-cultural Studies (CRCS) Universitas Gadjah Mada, Zainal Abidin Bagir mentioned 37 cases (compared with 10 cases issued since this law issues) prosecuted by Article 156a of the Criminal Code related to Prevention, Abuse and Defamation of Religion from 2000 until 2011. Some cases are about the fake prophet, Lia Eden (2009), Ahmad Mushodiq (2008) Sumardi Tappay (2006), Mahdi (2005) and many others.

The term "Penodaan" is interpreted as any activities that have the character of "deviation" from "basic teachings of religion". It refers to article 4 that mentions public speaking as part of propaganda in defaming certain religion. Therefore, this blasphemy provision in the Presidential Decree No.1/PNPS/1965 has also inspired the use of similar provisions in more recently laws. At least two laws have been used to prosecute people accused of "defamation religion" First, two sections of Law No.11/2008 on Electronic Information and

23 Amnesty International, Prosecuting Beliefs Indonesia's Blasphemy Laws (London: Amnesty International, 2014), 7. 
Transaction (UU Informasi dan Transaksi Elektronik or ITE Law) are used. Although Article 28 (2) of this law speaks of information "aimed to inflict hatred or hostility [against] individuals," it has in practice also be used to prosecute individuals who have been accused of defaming or insulting a religion online. Article 28(2) of ITE Law applies to:

"Any person who deliberately and without right disseminates information aimed to inflict hatred or hostility on individuals and/or certain groups of community-based on ethnic groups, religions, races, and inter-groups (antar golongan)."

Under the ITE Law, any individual convicted could face up to six years' imprisonment and a fine of up to 1 billion rupiahs. This penalty is higher than the provision found under Law No.1/PNPS/1965 on the Prevention of "Religious Abuse and/or Defamation". The second law used to prosecute people accused of blasphemy in Law No.23/2002 on the Protection of Children, which stipulates in Article 86 that:

"Any person who deliberately uses deception, a series of lies of persuades a child to choose another religion not of his/her own will, even though the perpetrator knows or should know that the child is not sufficiently intellectually developed and responsible enough to make such a choice in accordance with their religion shall be punished with imprisonment of 5 (five) years and/or a maximum fine of Rp100.000.000 (one hundred million rupiah).

Those laws show that the discourse of blasphemy in the Indonesia context is increasing in criminalizing religious expression in various context.

Blasphemy trials are often portrayed as remnants of the premodern failure to separate religion and politics, an affront to what Latour (1993) calls 'the modern Constitution'. ${ }^{24}$ Kari Telle who wrote about the case of Lombok related to the blasphemy law argued that

24 Talad Asad. Formations of the Secular: Christianity, Islam, Modernity. Stanford: Stanford University Press., 2003 and Sullivan, Winnifred Fallers. The Impossibility of Religious Freedom. (Princeton, NJ: Princeton, 2005). 
Indonesian blasphemy trials belong firmly within a tradition of the legal secular, illustrating the pivotal role of law in defining the boundaries of religious life, not only in Indonesia but also in late modernity more generally. It means that blasphemy trials occupy a pivotal role in 'religion-making' in post-1998 Indonesia. Examining a blasphemy trial on the island of Lombok in 2010, Kari Telle argued that the process of democratization has given civilian actors more opportunity to engage Indonesia's blasphemy law, a process analyzed in terms of 'lawfare'. ${ }^{25}$

\section{Ahok, Blasphemy and Religious Sentiment}

The term "Penodaan Agama"-and all words that express the same meaning becomes so popular in the social media after increasing protest toward the former Governor of Jakarta, Basuki Tjahaya Purnama or known as Ahok. This controversial case is based on the video that is shared through YouTube about his speech in commenting Al Maidab verses 51. Then, it is invited serious protests and anti-Ahok sentiment movement to at a boiling point after the politician cited a Quranic verse. The religious verse suggests that Muslim should not take Jews or Christian as their allies or leaders and his remarks, Ahok said that Indonesians should not be deceived by his opponent who use the verse to influence the election.

This case begins when a video published on social media, in which he mentioned Al Quran Al-Maidab: 51 during a working visit to Kepulauan Seribu regency on September 27. A day after visitation, the government published the full video with duration 1: 48: 33. But, after 9 days, Buni Yani uploaded video footage on his Facebook page by titled "Penistaan terbadap Agama" with its transcript that had been edited by cutting 30 seconds and erasing the word "pakai". He writes "karena dibohongi surat Al maidah 51" from its original video "karena dibohongi pakai Surat al maidah 51".

${ }^{25}$ Kari Telle. "Faith on Trial: Blasphemy and 'Lawfare' in Indonesia." Ethnos Journal of Anthropology, (2017), 1-20. 
Then, Buni Yani was accused of having edited video footage of Ahok to make it appear not as if the governor was criticizing people who were misusing a verse from the Quran, but was criticizing the Quran itself. After the video became available online, such as on Buni's Facebook page, it sparked widespread public anger.

Ahok denies that he insulted verses in the Quran. He mentioned the Al Maidah verse because the verse is often used by his political opponent to encourage people not to vote for him. However, October 10th, 2016, Ahok asked forgiveness publicly. Unfortunately, one of religious organization Majelis Ulama Indonesia (The Indonesian Ulama Council-MUI) a day after Ahok's apology statement, they accuse Ahok of Religious Defamation. ${ }^{26}$ MUI officially announced that Jakarta Governor Basuki “Ahok" Tjahaya Purnama committed blasphemy in his statement that cited a verse from the Quran. This statement comes from the MUI Chairman Ma'ruf Amin who said that Basuki Tjahaya Purnama's (conduct) can be categorized as insulting the Quran and Ulamas, which has legal consequences. This religious statement was followed by Secretary General of Front Pembela Islam (the Islam Defender Front-FPI) Novel Chaidir Hasan filed a report against Ahok with the National Police's Criminal Investigation Agency (Bareskrim) for religious defamation.

As explained before, this controversial statement also invites serious Islamic movement in the street, what is popular by the movement of 411 and 212. Before this movement, the rally was initiated by FPI leader Habib Rizieq Shihab, whose personal website published the call for a rally on October 23 . On the rally poster, it was written that the rally supported the MUI on Ahok and the $\mathrm{Al}$ Maidah 51 case. In this rally, Jokowi was being accused of protecting Ahok from the law. Both the movements 411 (November 11th) and

26 Jakarta Post. MUI Accuse Abok of Religious Dafamation. 12 October 2016. www.jakartapost.com (accessed by February 2017). 
212 (December 2nd) which demanding imprisoning Ahok for religious defamation are popular as Aksi Bela Islam.

On November 4, over 100.000 people, mostly from various Muslim groups, swarmed onto Jakarta's streets to demand Ahok's prosecution for alleged blasphemy. After weeks of investigations, the National Police have named incumbent Jakarta Governor, Ahok as a suspect in a blasphemy case, a move that may jeopardize the gubernatorial candidate's effort to seek re-election. ${ }^{27}$ This news becomes so popular in the media social that present various reactions and perspectives of citizens that will relate how they understand "penodaan agama".

Blasphemy law aims to protect religion from being insulted, but the problem is when blasphemy trials displaced religious disputes into the legal system which serve a particular interest. Religious authority and certain religious movement use allegations of blasphemy to repress individuals or groups that are perceived to face their authority and to end what are considered to be non-standard interpretations of mainstream religion. ${ }^{28}$ In the case of Ahok, Maarif Institut for Cultural and Humanity describe that the movement of "Bela Islam" shows religious authority can be stronger compulsion to gain their goals and influence the authority of the state. ${ }^{29}$ The other analysis of Bela Islam movement is explaining how the conservative's religious movement have been winning the society attention and bring it in the moderns and popular culture of religious life. ${ }^{30}$ Eurasia's Indonesia analyst Achmad Sukarsono said that the rallies don't want dent

\footnotetext{
27 Jakarta Post. Abok Named Suspect in Blasphemy Case. 16 November 2016. googleweblight/?lite_url=http:/the jakartapost.com/news/2016/11/16/ahoknamed-suspect-in-blasphemy-case (accessed by February 17, 2017).

${ }^{28}$ Melissa Crouch. "Law and Religion in Indonesia: The Constitutional Court and the Blasphemy Law." Asian Journal of Comparative Law, 7(1), (2014), 1-46.

29 Zainal Abidin bagir and Ahmad Imam Mujadid. "Setelah "Bela Islam": Gerakan Sosial Islam, Demokratisasi, dan Keadilan Sosial ." Maarif, Desember (2016), 4 15.

${ }^{30}$ Mohammad Iqbal Ahnaf in Maarif, Desember 2016, page 30 - 43.
} 
Ahok's chances of victory on governor election because of the bulk of the Jakarta electorate maintains a more liberal stance. ${ }^{31}$

Those explanations do not try to bring this study to political sense of the case or even discuss the law aspect of religious defamation. The explanation of chronology of this case becomes the context of this paper object that will elaborate the map of meaning 'penodaan agama' or 'penistaan agama' in the social media for the Ahok's case of Al Maidah 51.

This paper emphasizes that the term "blasphemous speech" or "blasphemy" will be used to encompass speech that is deemed disrespectful of God or the divine. Then, it will be portrayed in a different sense by cited studies. Violent crimes against persons or property motivated by religious animus (e.g., assaults on persons or the desecration of religious sites) are hate crimes and not treated in this paper as "blasphemy," which we view as relating solely to incidents involving speech without physical harm to persons or property.

\section{How Media Works in Popular Religious Blasphemy}

The first approach of the three perspectives is networking topic. This is the way the study search and find the topic that rises in tweets. The popular words which are coming up frequently can lead to the keyword of the topic. That's why by finding a certain hashtag, it is followed by another related hashtag then make certain networking topics and actors.

This paper focuses on the hashtag of "penodaan" and some related hashtag on it. Hashtagfy identifies there are some hashtag related to this issue, there are \#pojoksatu $(63,6 \%)$ by correlation 16,7 $\%$ and \#menangkanIslam (40,2\%) by correlation 4,2\%, \#Ahok 53,4\% by correlation 20,8\%, \#nasional $59,9 \%$ by correlation $43,8 \%$.

\footnotetext{
31 cnbc.com. How the Islamic State is Exploiting Jakarta Elections. 10 November 2016. www.cnbc.com (accessed by February 21, 2017).
} 
Keyhole.co records hashtag \#penodaanagama also has more significant impressions from internet user, in five days from February 13th until February 20th, there are 25 posts from 11 users that have 13.660 reactions and 44.875 impressions. The related topics that can be found through this hashtag are \#sidangabok \#saksisidangahok, \#jakarta.

The interesting result on this is when the hashtag is changed into \#penistaanagama, more hashtag has been made, \#PemimpinMuslim (30,1 $\%$ by correlation $12 \%)$, \#Penjarakan Ahok ( $45 \%$ by correlation $10,3 \%)$, and \#AhokPenistaAgama (28,8 by correlation 6,1\%). Hashtag \#penistaanagama also have 67 posts in only a day (20th - 21st February 2017) from 59 users and made 863.866 reactions and 1.173 .272 impressions on it. This hashtag becomes more popular when one of twitter account comes from The Indonesian House of Representatives (DPR) Fahri Hamzah who has 406.000 followers. The other influence comes from @jpnncom, @jalanIslam, @ malvadhina. There is also another member of DPR that intensely comment using hashtag \#ahok as a reaction to blasphemy case, he is @ Fadlizon who suggest the Central Government to fired Ahok as the Governor of Jakarta.

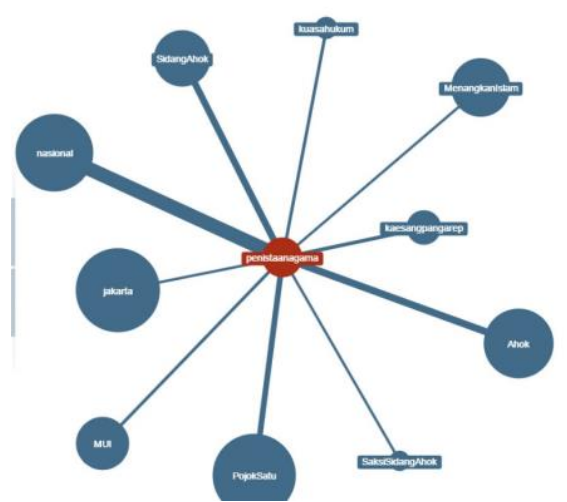

Picture 1. The result from hashtag \#penistaanagama in Hashtagify

In mapping various issues of blasphemy, the core hashtag that can be revealed related topics in large scales is hashtag \#ahok. From 
this hashtag, will rise 48 hashtags, they are \#alumni212, \#tangkappenista, \#aksibelaislam, \#pilihgubernurmuslim, \#belaquran, \#ahokers, \#muslimvotemuslim, \#jews, \#jakarta, \#pemimpinmuslimuntukdki1, \#jews, \#jakartabanjir, \#aby, \#moslem, \#terbuktimenista, \#saveulama, \#tolakpemimpinkafirpenistagama, \#sekuatbadja, \#pp51m, \#aksi212, \#penjarakanahok, \#savenkri, \#akutitipkansuara, \#ahokfitnaulama, \#saksisidangahok, \#stopkriminalisasiulama. Those hashtags are so important in portraying how one issue becomes more complex as before.

The other finding is when the hashtag "penistaan agama" is replaced by word “AlMaidab”, on March 8, 2017 through Netlytic, it is found that there are 94 posts from 16 users that make 45.639 accounts reacted and 128.621 give impressions. The hashtag words are "alMaidah51" (464 mentioned), a hashtag "\#harampemimpinkafir" (343), and "\#memilihpemimpinmuslim" (188). Three of them have strong correlation since the mainstream Indonesian Muslim understanding about the verse of $\mathrm{Al}$ Maidah 51 is about leadership. Muslim cannot accept the non-Muslim leader in the government or other organization when most of the members are Muslim. The debate of this verse is about the meaning of "awliya".

Now, I use the word "aksi-Bela Islam" in Keyhole.co that find there are 184 posts from 51 users and make 69.729 reactions and invite 116.067 impressions. This word refers to the protest movement that brings various Muslims from different places come to Indonesia in demanding to imprison Ahok for his blasphemy. The movements also bring the hashtag \#aksisuperdamai212, \#kamialumni212, and \#spirit212.

The debate on these issues shows some of them about how far non-Muslim would or should not talk about Al Quran and Islam. The agenda of Aksi Bela Islam tries to highlight that there is no other meaning of awliya except "leader" that means Muslim should vote 
Muslim. For example, there are two accounts are debating about voting for Ahok and Muslim's belief.

26 February 2017

(a) boytaradopi "jangan melarang Umat Islam untuk memilih Ahok" $\rightarrow$ @ didi_yusuf tha kamu melarang umat islam menjalankan aqidabnya kalo bgtu. Jelas itu sara, intoleran. W kwkwkwkw dasar! $\rightarrow$ "Muslim kog dukung Ahok, kitab suci ente al quran juga? @dede_yusuf

Based on the number of hashtags that have been collected, it can be concluded that the use of the word "penistaan" or/and "penodaan" in the Ahok case is colored by various discourses related to the meaning of blasphemy in social media. The use of the word "penistaan" begins with controversy about Muslim leadership, this discourse develops rapidly and massively in political mobilization, social even economy. This case is in the spotlight of several national and international mass media, and by some parties, both academics and public commentators began to analyze this issue for size the process of democracy in Indonesia.

Political mobilization in the vortex of hashtags "penistaan" in the Ahok case, demonstrated by propaganda about Muslim leadership. It can be shown from the popularity in the hashtags \#pemimpinMuslim, \#pilihgubernurmuslim, \#muslimvotemuslim, \#harampemimpinkafir, \#memilihpemimpinmuslim, \#tolakpemimpinkafir penistagama, and \#janganpilihahok. At the same time as the demand to imprison Ahok, propaganda for Muslim leadership became aggressive spread agendas. Social mobilization is shown by using the hashtag \#aksibelaislam that brought several issues on mass action in demanding "justice". There are two Islamic movements known as 411 and 212, which is spread through social media. Many people flocked to Jakarta to attend a peaceful parade demanding that Ahok is imprisoned for alleged blasphemy. Some of the hashtags used for campaigning the movement of Islamic defenders are \#aksi112, \#aksidamai411, \#ahokpenistagama, \#penjarakanabok, \#tangkapahok, \#aksibelaquran, \#spirit212, \#menangkanislam, \#kawalfatwaMUI, 
\#aksisuperdamai212 \#aksibelaulama, \#aksibelakativis, \#SaveUlama, and \#SupportDakwah.

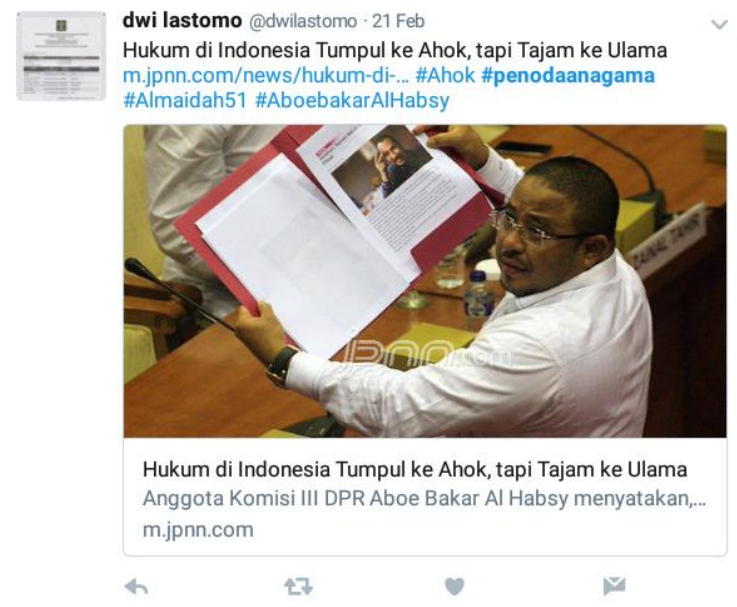

Picture 2. One of example news in media social that use hashtag \#penodaanagama for defending Ulama

The meaning of Bela Islam is not only referred to defending $\mathrm{Al}$ Quran, as the case concern before, this meaning grows fastly in the same time of issues in the court. For example, the issue of criminalization of ulama that use hashtag \#belaulama, \#kawalfatwaMUI, and \#aksibelaulama. In the middle of the court, the chairman of the Indonesian Ulama Council (MUI) Ma'ruf Amin testified during a hearing as part of Jakarta Governor Basuki Ahok" Tjahaya Purnama admitting that he did not have any call with the former President Susilo Bambang Yudhoyono about the relationship with a religious statement of blasphemy toward Ahok. In responding of this, people add hashtag \#marufamin in the line with hashtag \#menangkanislam, and more hashtag comes such as \#FPI \#fatwamui \#gnpf \#bubarkanGNPFMUI. 
In short, the hashtag has been classifying in six issues as explained before:
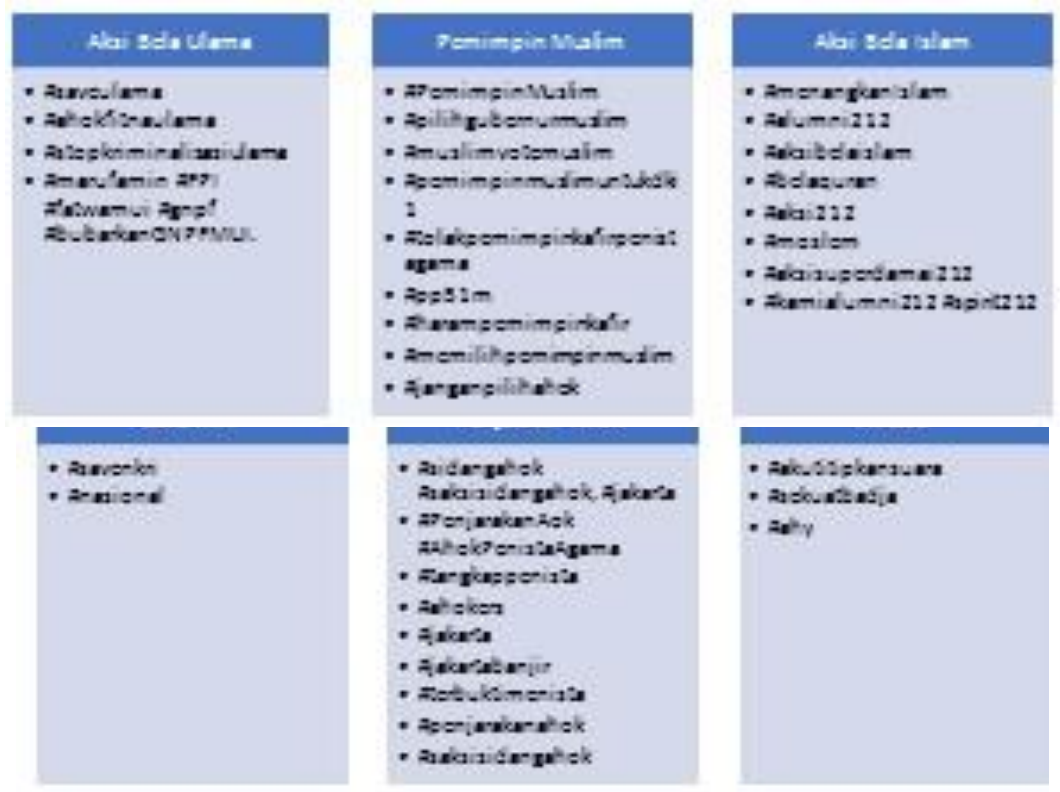

The six issues that are coming up based on the case of Ahok allow us to know the structure of language which works in the discourse. Someone who believes that Ahok is doing a religious blasphemy because of his words, then he must also be responsible to sue Ahok for his mistake. This is because the problem of religious blasphemy is not only a political issue, but also a matter that will threaten $\mathrm{Al}$ Quran, Ulama, Islam and even Indonesia as a country. Critics of the Quran are believed to require Muslims to elect Muslims as their leaders are seen as attempts to overthrow Islam. Therefore, to uphold the dignity of Islam, Al Quran, and Ulama, then ahok should be punished for his actions. This is how the logic structure of some netizens justify their actions and ideas through hashtags.

The campaign is also supported by various posters that attract Muslim enthusiasts and are distributed from many accounts. As a medium of propaganda, it is interesting to notice, the naming of $A k s i$ 
Bela Islam. This defensive view is a reflection of the worldview that defines the deterioration of the people due to outside attacks as well as the disobedience of the people to the pure teachings of Islam. With the slogan "kembali ke Quran and Sunnah", the worldview that lived in the early 20th century advocated the reading of Islam textually. The attempt to reconstruct methodologies and interpret Islamic teachings may be suspected as a rupture of a complete doctrine. Various attempts at different arguments will be easily accused of not defending Islam, liberals, hypocrites and even pagans. With that position, the supporters of Action 411 believe that their actions are merely defending beliefs and will strongly refuse to be accused of warming up on issues related to SARA (ethnic, religious, racial, and intergovernmental).

The second approach of the three perspectives is networking actors. The most popular accounts using hashtags "penistaan" and/or "penodaan" is @ fahrihamzah, while the account most often tagged in the issue is @basuki_btp. The other account correlated with @basuki_btp is @jpnn.com. This account constantly reports the process of the court and some news on sensitive issues through the time of Ahok's case. The other most influenced account on this hashtag is@BatamPost, @JalanIslam, and @Malvadhina.

The result of hashtag will be more interesting by entering the keyword \#aksibelaislam. In this hashtag shows some actors who aggressively campaign the Muslim mobilization "Aksi Bela Islam". The accounts are @DPP_FPI (83.463 followers), @hidcom (63.544 followers), @PrijantoRabbani (31.418 followers), @PejuangSubuh (205.486 followers), @ustadzzhilman (82.395 followers), @ bachtiarnasir (106.207 followers). The campaign was also spread by "ustadz celeb" (the Muslim leader who popularized by mass/electronic media), like Abdullah Gymnastiar, Yusuf Mansur, Subkhi Al Bughury, and Felix Siauw. They can influence the masses mainly from the middle class. 
The result will change if the password is changed, the hashtag \#almaidah51 shows more complex, there so many accounts involved in this network. Hashtagify shows six of the most influenced accounts based on the number of followers, there are @ fahrihamzah (485.100 followers), @fadlizon (531.736 followers), @TofaLemon (72.729 followers), @RonaVioleta (17.471 followers), @ chirpstory (95.510 followers),@hafidz_ary (88.802 followers).

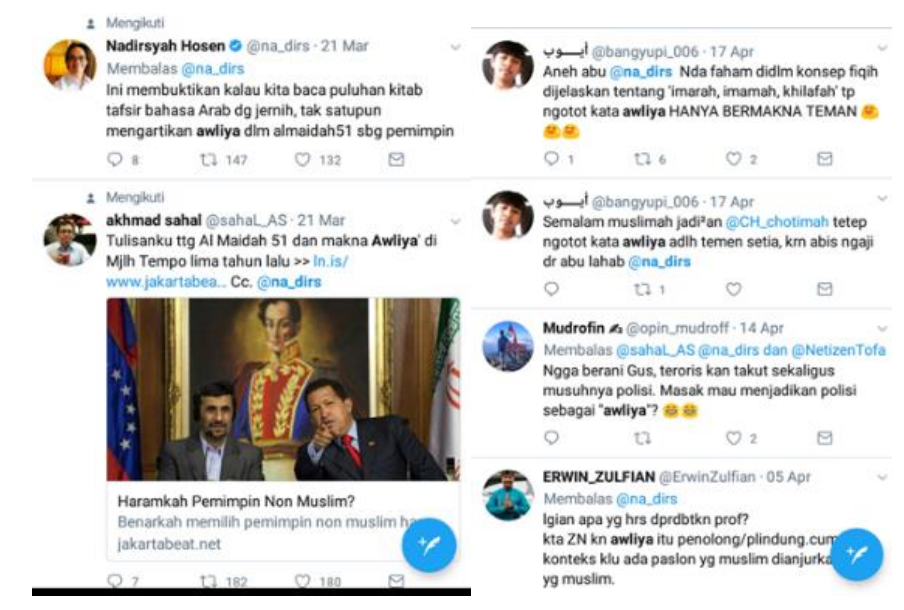

Picture 4. The examples of tweets that used keyword Almaidah51 and how the meaning of awliya' is debated between accounts.

From other hashtag search engine, Netlytic reports that there are 1096 post on Twitter that uses hashtag \#almaidab51, some the topics mentioned \#harampemimpinkafir (365), the word "ulama" (369), "tafsir" (205), "pemimpin” (134), “lecehkan” (204), “nistakan" (204), "memaksakan" (177), "agama" (210). "Ahok" (143) and a popular Twitter account@na_dirs (384). This account has 52.000 followers and specifically discuss awliya, the controversial term in Al Maidah 51. His explanation about "awliya" that has several interpretations invite serious debate toward who belief that the meaning of "awliya" is only "pemimpin". The other account who support@na_dirs is an account @sahaL_AS who also writing his idea on how "awliya" should be 
interpreted. His most popular tweets have been retweeted for 147 times.

Netlytic shows five configurations of the most popular accounts by showing many retweets their opinions.

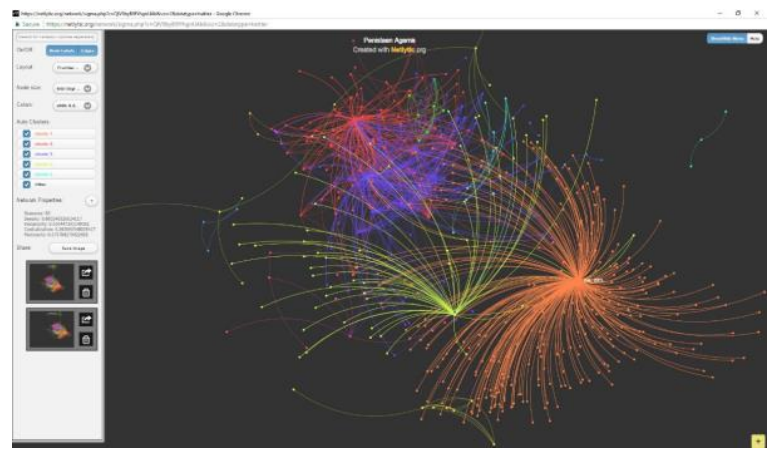

Picture 5. The Network of \#almaidah51 in Netlytic.

This network is made by Netlytic to describe the relationship between actors who are active on twitter. Previously, netlytic explained that what is meant by cluster above is "Name network is a communication network built from mining personal names in the messages. To discover ties in Name networks, a user can choose from two primary options: 'connect a sender to all names found in his/her messages' and/or 'connect people whose names co-occur in the same messages."

Keyword almaidab51 is more popular and widely used to describe the constellation of religious defamation in the case of Ahok than on other keywords. Therefore, on Netlytic, I use it to find five actors who have most responded through retweet or reply on their tweet. Five accounts are described as five clusters as shown above. They are @na_dirs (code by orange configuration), @ssirah (code by green), @sahal_as (code by blue), @grand_light88 (code by red), and @ militat vespa (code by tosca). Each of them has a role in spreading the controversion of Al Maidah in describing Blasphemy on the 
course of Awliya'.@na_dirs is the most popular account in this network, that influence more than 302 people. His cluster as below:

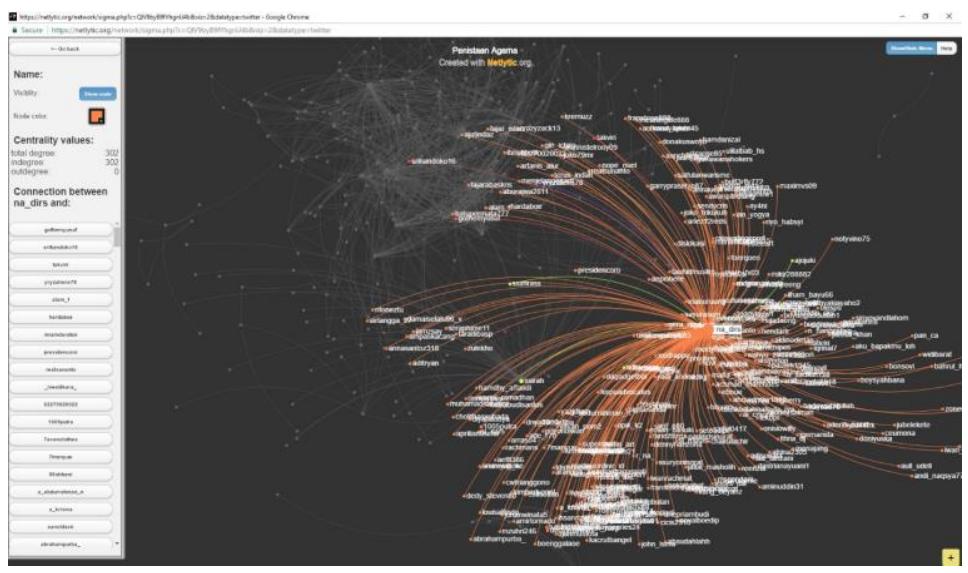

Picture 6. The cluster of @na_dirs in Netlytic.

He has three most popular tweets that discuss about the meaning of "awliya":

a. "Lho ZN kan sdh blg di videonya bhw awliya dalam almaidab51 artinya protectors. Belian tdk blg pemimpin ()) bttps:/ / m.youtube.com/watch?v=feiTsSYMw58 ..." 15 replays 138 Retweets 98 Likes (12:30 AM - 9 Mar 2017)

b. "Knp almaidah51 jd panjang diskusinya? Krn ada pibak yg memaksakan 1 versi terjemahan dan menganggap mrk. yg berbeda sbg mengingkari Qur'an" 14 replays 137 Retweets 85 Likes. (1:38 AM - 10 Mar 2017)

c. "Celakanya sebagian ustad\%, da'i dan khatib yg sebenarnya paham kitab tafsir justru memilih tdk mengungkap perbedaan tafsir almaidab51". 4 replies 86 retweets 56 likes (March 10th 2017)

$\mathrm{He}$ indicates that most people ignore the different interpretations in the meaning of awliya. His opinion invited many reactions that agreed or disagreed. In contrary, @ssirah indicates that Ahok's statement that understanding the Qur'an as a tool to politicize is tantamount to impose the interpretation of Al Maidab in 
accordance with his version. He said "Terdakwa memaksakan tafsir quran ayat almaidab51 versinya sj yg bnr walau tanpa ilmu, menudub Muslim yg pemahamannyabeda.”@sahal_as does not have a significant effect in spreading his ideas on the network, unfortunately, his name is mostly mentioned by who disagreed with him in defending Ahok.

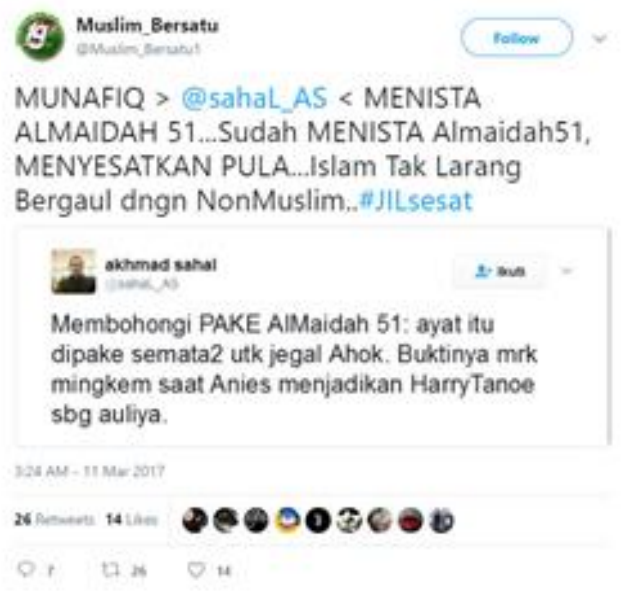

Picture 7. One of popular retweet from @sahal_as's tweet in reacting the blasphemy case.

The interpretation of awliya is important in this case of blasphemy because of some considerations. First, by knowing the tendency of an actor in understanding the meaning of awliya it will be followed by labeling who on whom. Labeling is the use of the word "munafiq" or "ulama su' " for actors who put forward different understandings and propose political factors as a way of imprisoning Ahok in the case of blasphemy. As for those who are struggling and actively carrying out the Qur'anic command to choose Muslims as leaders and also convinced that Ahok is making a blasphemy into a group that is described as a consistent Muslim in practicing of the Quran. Secondly, awliya tells us that the notion of "blasphemy" comes from an understanding of the scriptural interpretation standardized in "pokok-pokok agama" which should not be interpreted beyond the mainstream sense or which is largely accepted by the 'ulama. The 
explanation of the other meanings of the word awliya becomes insignificant because of mainstream meanings and political tendency. The impression is on how many Muslims feel offended because of Ahok's speech about the practice of Al Maidah 51 in choosing Muslim leaders.

\section{Discourse of Religious Blasphemy}

For Indonesia netizen, the word "penistaan" (blasphemy) is often described as an interpretation of religious doctrines (in this case is Islamic teaching) that considered disrespectful or irreverent of by words or conducts. The question of this paper, how Indonesian netizen in social media understand the blasphemy case of Ahok which is portrayed by various issues and topics that found in dialogue and debates. Some topics are campaigned to influence the netizen regarding the serious threat of blasphemy. Ahok's opinion about $\mathrm{Al}$ Maidah 51 invites the anger of the Muslim community who understands it as a form of threat that continues to be reproduced. As a public figure, Ahok is a good target to show how bad nonMuslim leader is. Starting from such a case, awareness of popular piety began to be introduced, disseminated and campaigned through topics which reproduced through a blasphemy case. Various topics of blasphemy will also rise some issues such as the interpretation of Qur'anic verses, Muslim/non-Muslim leadership, the criminalization of ulama, liberalism, Chinese threats to the political issue of the rebellion against the President of the Republic of Indonesia.

This study analyzes the findings of blasphemy discourse in the twitter in three steps. First, categorizing Indonesia netizen in the way they understand blasphemy. Second, analyzing the way the discourse influences the society. Third, explains social significance will be followed by social consequence of how Indonesia netizen preferring their understanding about blasphemy.

The tweets of Indonesia netizen about Ahok's case broadly speaking are divided into two opposites groups on fighting over the 
meaning of blasphemy. For one group, blasphemy means threatening toward the existence of religion, mainly Islam. For another, blasphemy is the political issue that used to "dismiss" the political opponent.

The social significance based on the first perspective -blasphemy is a religious issue- is some topics campaigned to influence the netizen regarding the serious threat of blasphemy. Ahok's opinion about $\mathrm{Al}$ Maidah 51 invites the anger among Muslim community who understands it as a form of threat. This meaning will also rise the feeling of fears as the consequence of threats. This fear is portrayed by various anxiety issues such as non-Muslim leadership, the criminalization of ulama, liberalism, and Chinese separatism effort of rebellion against the President of the Republic of Indonesia. Furthermore, how netizen reacts toward Ahok in blasphemy's case becomes the way to identify them as "Muslims" and building lines to differentiate with others. The popular meaning of "penista" becomes "the enemy of Muslim" that insult the sacred of Quran. The meaning of "pious" is in line with how far Muslim will fight for defending their identity.

The second perspective of blasphemy - political discourse- will try to encounter the religious discourse of blasphemy and proves that the accusations against Ahok are only political attempts to obstruct Ahok in the regional head election. This understanding can be found in the word "ayat itu semata-mata dipake untuk.jegal_Ahok" by@sahal_as who is rejecting the issue of blasphemy used for discriminating minority, even in the political sphere.

The social significance of the second perspective is interesting. Besides, they realize that the accusation against Ahok is a political trick, but they also use 'religious discourse' to argue the understanding of the source of blasphemy's case which is single interpretation on the religious source. They try to clarify the meaning of controversial words of Ahok and the diverse interpretation of the Quranic verses. 
This group uses some topics, such as Al Maidah, Awliya', tolerance, respecting the differences, democracy and rejecting SARA (Suku, Ras, Agama, dan Antar Golongan/ tribe, ethnicity, religion, and groups) issues.

The social consequence based on those developments of discourse is the conflict will not only occur in cyberspace, but also influence people identify the others based on their preference in Ahok's case. Of course, this is not as simple as it is look like. However, starting from such a case, the popular piety politically began to be introduced, disseminated and campaigned through topics which reproduced by a blasphemy case. In the case of Ahok, the issue is the obligation of Muslims to elect Muslim leaders. This requirement becomes vital to identify how pious a person is and how obedient Muslim is to their Shari'a. Therefore, the social consequence of religious discourse which should be noticed is the emancipation of religious awareness in their teachings and political point of views. While the social consequence of political discourse is the emancipation of religious sentiments and mobilizations.

\section{Conclusions}

Social media becomes an open space where information, opinions, and arguments take place in an egalitarian manner. In some cases, some expert opinions must also deal with various responses and opinions from various accounts that are not even known their background except what is written in their profile. Such a space has some advantages in terms of how information and opinions are spread and related easily. All ideas, information, knowledge, and also the policy are tested in netizen's perception. Therefore, it is very interesting to know how a mass movement involving thousands of people took to the streets through the viewpoint of netizens, who directly or indirectly gave a picture of their perception of what to fight for. 
The issue of "blasphemy" suddenly becomes the obligation for everyone to know and to understand. They are expected to condemn the perpetrator as the reaction of defending their religion. As the findings of this study, the way people identify "blasphemy" is at the same time also used to identify certain groups/actors. Generally, so many issues, themes, and topics which are found in the discourse of blasphemy, such as Islamic leadership, defending of Islam and Ulama, imprisoning Ahok and saving NKRI. Those themes show two conflicting group, a group who use religious discourse to identify "blasphemy" as a threat to religion and state and a group who use political discourse to identify "blasphemy" as a way to get rid of political enemies.

The interesting thing in the process of identification, the religious discourse emerges a similar solidarity in interpreting "blasphemy" based on a single interpretation of the Qur'an. So that, the different religious backgrounds should be agreed in this single interpretation. Consequently, they are demanded to participate in some social movements in defending Islam from blasphemy. For political discourse, the meaning of blasphemy is shown how religious interpretation is politically used for certain interest. That's why, in this discourse, the topics also use religious terminologies for clarifying "blasphemy" and "religious interpretation".

It is difficult to determine which of the two discourse is more dominant than the other. Both of them have their strength to involve the discourse of blasphemy without any borders in Twitter. Hopefully, this research can provide the map of the discourse of "blasphemy" in order to know how people construct their understanding, how they debate and try to influence each other in spreading those meanings. 


\section{Bibliography}

A Freedom House Special Report. "Policing Belief the Impact of Blasphemy Laws of Human Right." freedombouse.org. t.tn. https://freedomhouse.org/sites/default/files/Policing_Belief_ Full.pdf (di akses 3 13, 2017).

Amnesty International. Prosecuting Beliefs Indonesia's Blasphemy Laws. London: Amnesty International, 2014.

Asad, Talal. Formations of the Secular: Christianity, Islam, Modernity. Stanford: Stanford University Press. 2003.

Bagir, Zainal Abidin, dan Ahmad Imam Mujadid. "Setelah "Bela Islam": Gerakan Sosial Islam, Demokratisasi, dan Keadilan Sosial." Maarif, Desember 2016.

Bartel, Megan. "Religious groups and "soft power" through the internet." Being Muslim in the age of Facebook, Youtube and Twitter Anthropological reflections on Media and Religion Symposium, April 18th-19th. Bamako, April 18-19th, 2013.

Bourdieu, Piere. Leçon sur la leçon. Paris: Minuit, 1982.

Boyd, D. M., \& Ellison, N. B. "Social network sites: Definition, history, and scholarship." Journal of Computer-Mediated Communication, 13(1), 2008.

Bruns, A., and J. E. Burgess. "\#Ausvotes: How Twitter covered the 2010 Australian federal election." Communication, Politics, and Culture, 44(2), 2011.

Center for Religious and Cross-Cultural Studies. Politik Lokal dan Konflik. Keagamaan Pilkada dan Struktur Kesempatan Politik in Konflik Keagamaan di Sampang, Bekasi, dan Kupang. Yogyakarta: CRCS UGM, 2015.

cnbc.com. How the Islamic State is Exploiting Jakarta Elections. 10

November 2016. www.cnbc.com (diakses February 21, 2017).

Cochran, A., L. S. Kao, N. J. Gusani, J. W. Suliburk, and B. C. Nwomeh. "Use of Twitter to document the 2013 Academic Surgical Congress.” The Journal of Surgical Research, 190(1), 2014. 
Crouch, Melissa. "Law and Religion in Indonesia: The

Constitutional Court and the Blasphemy Law." Asian Journal of Comparative Law, 7(1), 2014.

Fairclough, Norman. Discourse and Social Change. Cambridge: Polity Press. 1992.

Foucault, Michel. Power and Knowledge. Brighton: the Harvest Press, 1980.

Gabriel, B. They must be stopped: Why we must defeat radical Islam and how we can do it. New York: Martin's Press. 2008.

Gruber, D. A., R. E. Smerek, M. C. Thomas-Hunt, dan E. H. James. "The real-time power of Twitter: Crisis management and leadership in an age of social media." Business Horizons, (2), 2015.

Habermas, Jurgen. "Hannah Arendt's Communications Concept of Power." SOCIAL RESEARCH 43(4), 1977.

Hermida. "Twittering the news: The emergence of ambient journalism." Journalism Practice, 4(3), 2010: 297-308.

Hidayatulloh, Taufk. "Penistaan/Penodaan Agama dalam Perspektif Pemuka Agama Islam di DKI Jakarta." Harmoni, Mei - Agustus 2014.

http:/ /dekandidat.com. Digitroops: Kasus Ahok dan Aksi Bela Islam Paling Populer Tabun 2016. 22 Desember 2016. http://dekandidat.com/2016/12/22/digitroops-kasus-ahokdan-aksi-bela-islam-paling-populer-tahun-2016/ (diakses Juli 17, 2017).

Jakarta Post. Ahok Named Suspect in Blasphemy Case. 16 November 2016. googleweblight/?lite_url=http:/the jakartapost.com/news/2016/11/16/ahok-named-suspect-inblasphemy-case (acessed at February 17, 2017).

-. MUI Accuse Ahok of Religious Defamation. 12 October 2016. www.jakartapost.com (diakses February 2017, 2017). 
Kaplan, A. M., dan M. Haenlein. "Users of the world, unite! The challenges and opportunities of Social Media." Business Horizons, 53(1), 2010: 59-68.

Kwak, H., Lee, C., Park, H., \& Moon, S. What is Twitter, a social network or a news media? Paper presented at the 19th International Conference on World Wide Web. NC: Raleigh, NC. doi:10.1145/1772690.1772751, 2010.

Lassen, D. S., dan A. R. Brown. "Twitter: The electoral connection? Social Science.” Computer Review, 29(4), 2010.

Latour, Bruno. We Have Never Been Modern. Cambridge: Cambridge University Press, 1993.

Lebl, L. "Radical Islam in Europe.” Orbis, 54 (1), 2010: 46-60.

Maireder, Axel, dan Julian Ausserhofer. "Political Discourses on Twitter: Networking Topics, Objects and People.” Dalam Twitter and Society, oleh K., Bruns, A., Burgess, J., Mahrt, M., \& Puschmann C. (Hrsg.) Weller. New York: Peter Lang, 2013.

Marshall, P. \& Shea, N. Silenced: How apostasy and blasphemy codes are chokingfreedom worldwide. New York: Oxford University Press. 2011.

Moe, A. O, dan H. Larsson. "Studying political microblogging: Twitter users in the 2010 Swedish election campaign." New Media \& Society; 14(5), 2011.

Moore, James R. "Blasphemy Laws and Hate Speech Codes: Threats to Freedom of Expression, Dissent, and Democracy." International Journal of Humanities and Social Science Vol. 3 No. 18, October 2013.

Munawar, Iffatkhalid \& Shamana. "Blasphemy Law of IslamMisconceptions and Fallacy." Journal of Islamic Studies and Culture, June 2015, Vo.3, No.1.

Oliveira, Papacharissi \& de Fatima. "Affective news and networked publics: The rhythms of news storytelling on \#Egypt." Journal of Communication, 62(2), 2012. 
Pew Forum on Religion and Public Life. "Laws penalizing blasphemy, apostasy and defamation of religion are widespread." 21 November 2012. http://www.pewforum.org/2012/11/21/lawspenalizingblasphemy-apostasy-and- defamation-of-religion (diakses May 7, 2017).

Phares, W. The War of Ideas: Jihädism against democracy. New York: Palgrave. 2007.

Recuero, Raquel. "Social Media and Symbolic Violence." Social Media + Society, April - June 2015.

Saragih, Bagus Budi Tama. NGOs Request Judicial Review of Religious Blasphemy Law. 30 January 2010. ttp://www.thejakartapost.com/news/2010/01/30/ngosrequest-judicial-review-religious-blasphemy-law.html (diakses March 14, 2017).

Schanzer, Jonathan, dan Steven Miller. Facebook Fatwa: Saudi Clerics, Wabhabi Islam, and Social Media. Washington, d. C.: foundation for the defense of democracies, 2012.

Small, T. A. "What the hashtag? A content analysis of Canadian politics on Twitter." Information, Communication \& Society 14(6), 2011.

Sullivan, Winnifred Fallers. The Impossibility of Religious Freedom. Princeton, NJ: Princeton, 2005.

tekno.liputan6.com. 3 Media Social Favorit Pengguna Internet Indonesia. 24 October 2016 http://tekno.liputan6.com/read/2634027/3media-sosial-favorit-pengguna-internet-indonesia (diakses February 21, 2017).

Telle, Kari. "Faith on Trial: Blasphemy and 'Lawfare' in Indonesia." Ethnos Journal of Anthropology, 2017.

The Wahid Institute. Annual Report. Jakarta: Wahid Institute, 2014.

Wodak, Ruth, dan Michael Meyer. Method of Critical Discourse Analysis. London: Sage Publication, 2001. 